\title{
Use of the multicriteria analysis methods to optimize sustainable energy systems based on renewable sources
}

\section{Uso de herramientas de análisis multicriterio para la optimización de sistemas energéticos sustentables a partir de fuentes renovables}

\author{
URBANO-ARCILA, Paola Andrea†*, LASTRES-DANGUILLECOURT, Orlando, HERNÁNDEZ- \\ GALVEZ, Geovanni and IBÁÑEZ-DUHARTE, Guillermo Rogelio
}

Universidad de Ciencias y Artes de Chiapas. Instituto de Investigación e Innovación en Energías Renovables. Estudiante de doctorado en Materiales y Sistemas Energéticos Renovables.

\author{
ID $1^{\text {st }}$ Author: Paola Andrea, Urbano-Arcila / ORC ID: 0000-0002-2321-8358, CVU CONACYT ID: 822755 \\ ID $1^{\text {st }}$ Coauthor: Orlando, Lastres-Danguillecourt / ORC ID: 0000-0002-7420-7173, CVU CONACYT ID: 252788
}

ID $2^{\text {nd }}$ Coauthor: Geovanni, Hernández-Galvez / ORC ID: 0000-0003-1500-0284, CVU CONACYT ID: 255374

ID $3^{\text {rd }}$ Coauthor: Guillermo Rogelio, Ibáñez-Duharte / ORC ID: 0000-0002-2437-1928, CVU CONACYT ID: 215574

DOI: $10.35429 / J U R R E .2020 .7 .4 .15 .29$

Received July 11, 2020; Accepted November 27, 2020

\begin{abstract}
Sustainable The sustainable energy development implies to look for balanced technological alternatives, economically, socially, and environmentally. Therefore, it is a complex process which solution is commonly supported on mathematic tools, whether multi-objective optimization (MODM) or multicriteria analysis (MCDM). In this work, an analysis of these tools in the field of the renewable energy is carried out, with the purpose of identify the hybrid renewable energy systems design under a sustainable view perspective, which implies the use of MCDM or MODM tools. The methodology used consists of identifying the references related to the design of hybrid renewable energy systems and the sustainability term, using the WOS (Web of Science) search engine, which were analyzed in chronological order to identify the basic forms of the methods, the application foundations, and finally, the perspectives, reflected in the most recent publications. MCDM tools were identified as the most used with the $71 \%$ of the analyzed references, above the multiobjective methodologies; being the most popular the Hierarchical Analytical Process (AHP) and the Order of Preference for Similarity with the Ideal solution (TOPSIS). It is important that the decision makers use such kind of tools, both to design and to plan sustainable energy systems.
\end{abstract}

Sustainable development, Renewable energy, Decisionmaking, Multicriteria analysis, Multiobjective analysis

\begin{abstract}
Resumen
El desarrollo energético sustentable implica buscar alternativas tecnológicas equilibradas, en lo económico, lo social y lo ambiental. Por ello, es un proceso complejo cuya solución suele apoyarse en herramientas matemáticas, ya sea de optimización multi-objetivo (MODM) o de análisis multicriterio (MCDM). En este trabajo se realiza un análisis de dichas herramientas en el campo de las energías renovables con el fin de identificar las perspectivas en el diseño de sistemas híbridos renovables, bajo un enfoque de sustentabilidad, empleando herramientas MCDM o MODM. La metodología empleada consiste en la identificación de las referencias relacionadas con el diseño de sistemas híbridos renovables y el término sustentabilidad, empleando el motor de búsqueda WOS (Web of Science), las cuales fueron analizadas en orden cronológico para identificar los métodos en sus formas básicas, los fundamentos para su aplicación, y finalmente las perspectivas reflejadas en las publicaciones más recientes. Se identificó que las MCDM son empleadas en el $71 \%$ de los casos analizados; siendo las más populares la de Proceso Analítico Jerárquico (AHP) y la de Orden de Preferencia por Similitud con la Solución Ideal (TOPSIS). Es importante que los tomadores de decisiones usen tales herramientas, tanto para diseñar como para planear sistemas energéticos sustentables.
\end{abstract}

Desarrollo sustentable, Energías renovables, Toma de decisiones, Análisis multicriterio, Optimización multiobjetivo

Citation: URBANO-ARCILA, Paola Andrea, LASTRES-DANGUILLECOURT, Orlando, HERNÁNDEZ-GALVEZ, Geovanni and IBÁÑEZ-DUHARTE, Guillermo Rogelio. Use of the multicriteria analysis methods to optimize sustainable energy systems based on renewable sources. Journal-Urban-Rural and Regional Economy. 2020. 4-7: 15-29

\footnotetext{
* Correspondence to Author (email: paolaurbano@ hotmail.com)

$\dagger$ Researcher contributing as first author.
} 


\section{Introduction}

Sustainable energy systems are a set of equipment and devices that transform the energy available in a given place, into useful energy, either electrical or kinetic energy for use at the moment or for storage and subsequent use. The nuance of sustainability implies that these energy transformation systems are economically favorable, technologically reliable and viable, and mainly environmentally friendly. Other dimensions of sustainability have been added in recent years, the social and institutional dimensions; that have been fundamental pieces in the implementation and fulfillment of the project period, being cases of success.

It is there where the application of multicriteria analysis tools (MCDM) or multiobjective methodologies (MODC) is required for decision making; since they allow solving situations that depend on multiple actors, criteria and objectives, especially when some objectives are opposed to others. They comprise five elements: the goal, stakeholder preferences, alternatives, criteria, and outcomes.

Traditionally, commercial software programs and methods for the design of renewable energy systems (HOMER, RETSCReen, TRNSYS, HYDROGEMS, HYBRID2, among others), contemplate a single objective that is generally economic or technical. Using these programs, a list of alternatives or configurations of renewable systems can be generated with the different combinations between the devices for the use of available resources (photovoltaic modules, wind turbines, mini-hydraulic turbines, pumps, heat biodigesters, gasifiers, among others. ) energy storage devices (battery banks, hydrogen storage, water pumping, flywheels, among others), backup systems (gasoline or diesel generators, electricity supply network) and adaptation devices and energy supply (inverters, charge controllers, converters, maximum power point trackers, among others); to cover a type of demand (residential, industrial, school, among others) determined by an annual profile and an average value of energy consumption.
The importance of identifying the perspectives on this issue is to establish the most used tools for the development and planning of renewable hybrid systems since the alternatives or configurations obtained allow to supply the energy demand given in a given site, some with higher investment costs, others with higher emissions, some that could cause discomfort to the inhabitants around the site, etc. It is there where the different aspects that favor or harm the sustainability of these systems intervene. Through the criteria or sustainability objectives, the alternatives are compared, and, according to the preferences of the users, an importance value is assigned to some over others to obtain the most convenient system, through the weighting of applicable weights. in the MCDM.

Currently there is a great variety of MCDM and MODM, applied in their basic forms, combined or with variations that imply a greater difficulty in the implementation to improve their precision. Hence the added value of identifying the most popular and most easily implemented tools for their application by users with different levels of preparation.

Around the world, hybrid power generation systems have been implemented (that take advantage of two or more renewable sources), with several success stories through the years for which it was conceived, and in some cases transcending that value. In the particular case of Mexico (Agredano, 2000), these systems have been, for the most part, dismantled long before reaching their lifetime, due to several problems identified: under or oversizing, deterioration of equipment due to environmental factors, increased energy demand, no refurbishment, no after-sales technical service, insufficient maintenance fees, disorganization in communities, lack of technology transfer. It is important to continue promoting this type of system, mainly in remote areas where there are still more than half a million Mexican homes that lack this basic service. By applying the most popular MCDM or MODM, the optimal sustainable energy system can be obtained, such that it supplies the required demand, during the entire useful life for which it was projected.

In the introductory section, the reader was contextualized in the topic to be developed, setting out basic guidelines to facilitate the understanding of the subsequent sections. 
In the methodology section, the steps followed for the bibliographic review of the references found are presented, in chronological order to facilitate understanding of the topic. The results present a classification of references in antecedents, fundamentals and trends, for the identification, understanding of MCDM and MODM, and trends. Subsequently, a discussion section is developed in order to visualize and analyze the different characteristics found in the review, to finally present the conclusions.

\section{Methodology}

For the information search, the tree of science platform (TOS-Core of science) is used, which provides a classification in the form of a tree, resulting from the interaction between the citations and the references obtained when entering the search keywords. related information.

\section{Tree of Science - TOS}

It is a platform developed by a research group from the National University of Colombia (Robledo-Giraldo et al., 2014) that arose from the need to establish the theoretical bases of a topic "X". A regular search for X generated 214 articles as a result; Following the established procedure, 1476 articles and 4212 citations were found. At the bottom of fig. 1 the tree can be seen. The root files in yellow represent the background, the trunk in brown represents the fundamentals, and the leaves in green represent the trends. From this breadbasket they were able to identify X's perspectives and how to develop the TOS platform.

Figure 1 presents a simplified guide to using TOS in bibliographic searches, which will open a broad overview of a topic of interest.

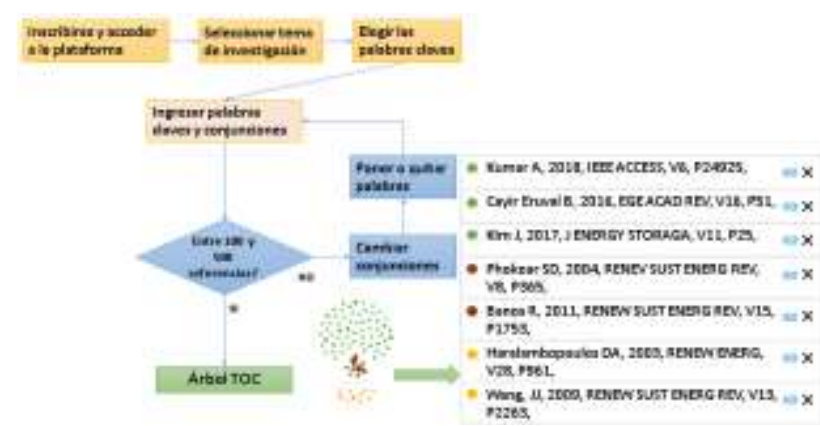

Figure 1 Block diagram for TOS users

Source: Own Elaboration a. Verify the subscription to the WOS (Web of science) search page and enter the selected topic (for this example it was "Hybrid renewable energy systems multicriteria optimization”). Only 11 references were found, insufficient to plant a tree. To obtain more references, the word "Hybrid" was eliminated and in this way 113 references were generated (the range is between 100 and 500 to plant a tree).

b. Export the bibliographic references and citations file to a txt file.

c. Enter the page tos.coreofscience.com and paste the previously generated txt file (the platform calls it a seed file).

d. Review the entries and click CONTINUE so that the tree is generated.

e. It is recommended to read the references selected by the platform in order of roots, trunk and finally leaves for a better understanding of the subject.

From the information analyzed, different comparisons, contrasts and classifications are made, represented in tables and graphs constructed by the authors, specific information that is presented more during the development of this writing.

\section{Results}

\section{Background (Roots)}

The first document suggested by TOS is the book "The analytic Hierarchy Process: Planning, priority setting, resource allocation" by the renowned professor Thomas L. Saaty in 1980, which is not found on the web, but refers to it in later publications (Dong, Q., Saaty, TL, 2014), in which the bases of the AHP (Analytic Hierarchy Process) multi-criteria tool are outlined. This methodology proposes a pairwise comparison of each of the criteria, giving a value taken from the Saaty nine-point scale. Subsequently, the normalization of each of the rows of the pairwise comparison matrix is carried out to obtain the value or weighted weight of each criterion. The classification of the alternatives is obtained by multiplying each criterion by its weight (taking into account the positive sign if the criterion is beneficial, and the negative if it is not) and performing the summation for each of the alternatives, in the matrix of decisions. 
Higher values will be the best, and the best rated alternative will be optimal. They establish the consistency index of the assigned values and the importance of evaluating it.

Georgopoulou et al. (1998) propose a procedure using PROMETHEE II (Preference Ranking Organization Method for Enrichment Evaluations) for the evaluation of various alternatives for the participation of renewable energy systems (RES). They compared the results obtained with AHP, MAUT (or MAVT, Multi Attribute / Value Utility Theory) and the previous version PROMETHEE.

Haralambopoulos \& Polatidis (2003) also used PROMETHEE II for the development of RES projects, a particular case of the geothermal resource. By 2006, Zhou et al. Published an update on energy and environmental decision models compared to a previous publication by Huang et al., In 1995. They found that the number of related publications had tripled.

Loken in 2007, established that most group decision-making methodologies (TDG) require several opposing considerations, and classified them into: measured value models (AHP, MAUT), objective, goal and level of achievement models. reference (GP (Goal programming), TOPSIS (Technique for Order of Preference by Similarity to Ideal Solution)), and improvement models (PROMETHEE II, ELECTRE III (Elimination and Choice Expressing Reality)). He applied the three types of methodologies for energy planning problems (EP), concluding that a single model is not applicable in all cases, that two or more must be used (in combination or in parallel) to take advantage of the strengths and minimize the weaknesses .

Tsoutsos et al. (2009) mention that traditional evaluation methods, such as cost / benefit analysis and macroeconomic indicators are not rigorous enough; and that the MCDM allow to interrelate a wide range of variables being a valid support for decision making. Wang et al. (2009) highlighted the increase in the popularity of MCDM in energy sustainability due to the multidimensionality of the objectives. They analyzed the different stages of the methods for (TDG) in RES projects such as the selection of the criteria, the weighting, the evaluation and the final aggregation.
They found that the weight-weighted method (WWM), equal weights, and the MCDM AHP, remained the most popular.

For their part, Connolly et al. (2010) reviewed the different existing computational tools for integrating RES to conventional systems. They included 37 out of 68 existing ones. They conclude that there is no single tool to address all options related to energy integration (EI) but they establish a useful guide to choose one of the tools, as appropriate. In another of the research roots references (Kaya \& Kahraman, 2010) they used VIKOR (Vlse Kriterijumska Optimizacija I Kompromisno Resenje (Serbian) / Multicriteria Optimization and Compromise Solution) and AHP to determine the best RES alternative for Istanbul, wind energy . Finally, Sengül et al. (2015) developed a proposal using the SEIM WWM (Shannon entropy interval) to prioritize energy supply sources in Turkey (first, hydroelectric).

The MCDM methodologies for TDG began to gain relevance towards the end of the 90 s, according to the analyzed antecedents. The main renewable sources studied in the world until then were wind, solar, geothermal and biomass. Table 1 presents a summary of the antecedents or roots (ROOTS) of this TOS.

\begin{tabular}{|l|l|l|l|}
\hline \multicolumn{2}{|c|}{ Author } & Methodology & \multicolumn{1}{c|}{$\begin{array}{l}\text { Energy } \\
\text { sources }\end{array}$} \\
\hline Saaty, 1980 & $\begin{array}{l}\text { General } \\
\text { energies }\end{array}$ & USES \\
\hline $\begin{array}{l}\text { Georgopoulou, } \\
1998\end{array}$ & $\begin{array}{l}\text { PROMETHEE } \\
\text { II }\end{array}$ & $\begin{array}{l}\text { W / SHy / } \\
\text { PV / }\end{array}$ & Greece \\
\hline $\begin{array}{l}\text { Haralambopoulos, } \\
\text { 2003 }\end{array}$ & $\begin{array}{l}\text { PROMETHEE } \\
\text { II }\end{array}$ & $\begin{array}{l}\text { ST / BM / } \\
\text { GT }\end{array}$ & Greece \\
\hline Zhou, 2006 & Review & GT & Singapore \\
\hline Loken, 2007 & Review & $\begin{array}{l}\text { General } \\
\text { energies }\end{array}$ & Norway \\
\hline Wang, 2009 & Review & $\begin{array}{l}\text { General } \\
\text { energies }\end{array}$ & China \\
\hline Tsoustos, 2009 & $\begin{array}{l}\text { PROMETHEE } \\
\text { I and II }\end{array}$ & $\begin{array}{l}\text { General } \\
\text { energies }\end{array}$ & Greece \\
\hline Connolly, 2010 & software & $\begin{array}{l}\text { W / SHy / } \\
\text { Hy / PV / } \\
\text { ST / BM }\end{array}$ & Denmark \\
\hline Kaya, 2010 & VIKOR-AHP & $\begin{array}{l}\text { General } \\
\text { energies }\end{array}$ & Turkey \\
\hline Sengul, 2015 & TOPSIS / FL & $\begin{array}{l}\text { W / Hy / } \\
\text { SHy / PV / } \\
\text { ST / BM }\end{array}$ & Turkey \\
\hline
\end{tabular}

Table 1 Background summary (Roots of TOS)

Source: Own Elaboration 


\section{Fundamentals (Trunk)}

The fundamentals developed in this section include the classification of MCDM tools addressed by Pohekar \& Ramachandran (2015) and by Baños et al. (2011). In the first work, the authors analyzed the methodologies identified in 90 publications, finding AHP as the most popular, followed by PROMETHEE and ELECTRE. They also analyzed interactive and fuzzy logic (FL) methods to reduce data uncertainty. In the second work, they analyzed the MODM based on the vital importance of energy for the integral development of emerging nations. Among the most used MODMs were MILP (mixed integer linear programming), MIQP (Lagrangian relaxation, quadratic programming) and Simplex; as well as heuristic techniques such as GA (genetic algorithms) and PSO (Particle Swarm Optimization).

In a bibliography focused on the bioenergy sector (Scott et al. 2012), they found that the most popular methods were those that gave a choice between few discrete alternatives, followed by the methods for choosing between several continuous and step-by-step alternatives. For his part, Bhattacharyya (2012) argued that electrification outside the grid is gaining importance in developing countries, for which he focused a bibliographic review on isolated systems (not connected to the grid), where he presented the strengths and weaknesses of the methodologies found, and recommended using a hybrid structure that combines two or more options to take advantage of strengths and mitigate weaknesses.

Perera et al. (2013) proposed a combination of MCDM and MODM to design a hybrid system W / PV (wind / photovoltaic), where they obtain the Pareto front (Obtained through MODM) and subsequently select the optimal RES using four criteria and applying a MCDM. On the other hand, Ribeiro et al. (2013) presented a proposal in Excel (MILP), to evaluate different energy production scenarios, for which they used 12 criteria, finding that the most expensive scenario was the one with the maximum renewable fraction and the most economical the one with the renewable fraction $0 \%$. Although the different alternatives with renewable fractions greater than zero, are more expensive, they substantially reduce emissions and energy dependence.
Coming to 2016, Çelikbilek \& Tüysüz, establish that RES alternatives should be considered in the energy portfolios of all countries that seek the most adequate energy resources to sustain their social and economic development. They presented a gray model similar to FL, integrating three methods: (i) DEMANTEL (Decision Making Trial and Evaluation Decision Making Evaluation Laboratory) to find interrelationships between the criteria; (ii) ANP (network analytical process) as WWM; and (iii) VIKOR for the evaluation and classification of the alternatives. Meanwhile, Kumar et al. (2017) stated that energy planning has become complex, due to the influence of multiple economic, technical, environmental and social points of view; these and more constraints must be faced by developers when optimizing energy alternatives for rural communities.

According to Arce et al. (2015), European energy systems are characterized by high dependence on fossil fuels and energy imports. An analysis of the energy system is required involving MCDM tools. Similar studies mainly evaluate technical and environmental parameters, using AHP as MWW. In the same year, Tahri et al., Established that environmental regulations are currently dedicated to promoting the development of RES in Morocco. The authors combined GIS (Geographical Information System) with MCDM tools the sustainability of the sites to implement RES. They found that weather conditions are the most important criterion, because they define the potential of energy resources, followed by orography. Table 2 presents a summary of the research reviewed during the analysis of the fundamentals (TRUNK), the trunk of the TOS.

\begin{tabular}{|l|l|l|l|}
\multicolumn{1}{|c|}{ Author } & \multicolumn{1}{c|}{ Energy sources } & \multicolumn{1}{c|}{ country } \\
\hline Pohekar, 2004 & Revisión & Energy in general & India \\
\hline Baños, 2011 & Revisión & $\begin{array}{l}\text { W/ST/Hy/SHy/H } 2^{-} \\
\text {T/BM/GT }\end{array}$ & España \\
\hline $\begin{array}{l}\text { Bhattacharyya, } \\
2012\end{array}$ & Revisión & PV/Madera aislados & Inglaterra \\
\hline Scott, 2012 & Revisión & Energy in general & Inglaterra \\
\hline Perera, 2013 & Revisión & W/PV/Batt & Sri Lanka \\
\hline Ribeiro, 2013 & GIS-AHP & W/Coal & Portugal \\
\hline Arce, 2015 & FL TOPSIS & $\begin{array}{l}\text { W/PV/ST/H } 2^{-} \\
\text {T/BM/GT }\end{array}$ & España \\
\hline Tahri, 2015 & Review & PV & Marruecos \\
\hline $\begin{array}{l}\text { Celikbilek, } \\
\text { 2016 }\end{array}$ & $\begin{array}{l}\text { ANP, } \\
\text { DEMATEL, }\end{array}$ & W/PV/ST/Hy/BM/GT & Turquía \\
\hline Kumar, 2017 & MIKOR & W/GAM/SHy/PV/ST/BM & India \\
\hline
\end{tabular}

Table 2 Summary of fundamentals (Tronco del TOS) Source: Own Elaboration 


\section{Trends (Leaves)}

The MCDM tools have been applied to the design of RES to promote renewable energies in sustainable use, in isolated systems (Strantzali et al., 2017; Ray et al., 2018; Hernández et al., 2014; Alsayed et al., 2014), to mitigate inherent variability in sources. While, in interconnected systems (Ray et al., 2018; Hernández et al., 2014; Alsayed, et al., 2014; Theodosious et al., 2015) it has been carried out to promote the diversification of energy sources, to reduce greenhouse gas (GHG) emissions and dependence on fossil fuels.

For example, the PROMETHEE II tool was implemented by Alsayed et al. (2014), for a RES W / PV interconnected to a PGS (power generation system). Subsequently, Strantzali et al. (2017) applied the same tool to an isolated W / NLG (Natural liquified gas) system with a fuel generator as a backup system. In a more recent publication (Ray et al., 2018), CSA (Cuckoo search algorithm) was applied for the design of a $\mathrm{W} / \mathrm{PV}$ system with a combined cycle gasifier digester.

Hernández et al. (2014), applied VIKOR, for the optimal selection of two RES; one of these W / PV interconnected to the network to supply the demand of the laboratories of a university on the isthmus of Tehuantepec. And another system, also W / PV, but isolated, for the electrification of a rural area in Cuba. In other studies of W / PV systems, TOPSIS has been applied in its basic form (Perera et al., 2015), or with FL defining the fuzzy TOPSIS tool (Theodosiou et al., 2015). For their part, Ifaei et al. (2018), applied the same tool to simulate a RES composed of PV / W / BG / HY / BM, as a pilot unit to evaluate the energy potential of Iran.

Bakhtiari \& Naghizadeh (2016), propose the SFLA / $\varepsilon$-constrain (Shuffled Frog Leaping Algorithm / Restrictions Ipsilon) tool, for the design of a RES W / PV / FC / Elec / H2 / Batt, with an intermittent demand profile. For a case study in England, (Malekpoor et al., 2017), they suggested the implementation of technologies with low $\mathrm{CO} 2$ emissions, reducing the use of coal and gasoline. They used the GRA-MOGLP Gray Relational Analysis- Multi-objective Gray Linear Programming MODM; being an effective tool for the evaluation, optimization and planning of sustainable electricity generation.
Subsequently, an adaptable, affordable and sustainable wastewater treatment system powered by a W / PV system, based on theory and technology, was proposed (Soni et al., 2017). Similarly, MacKenna et al. (2018), presented the MILP (RE3ASON) / MAVT proposal for energy planning, using renewable sources such as W / PV / BM.

Trutnevyte (2018), developed the EXPANSE (EXploration of Patterns in Nearoptimal energy ScEnarios) methodology for the design of RES and their interaction with sources for the evaluation of the economic potential of RES from a hybrid perspective (energy mix), with in order to address two limitations of the evaluations of the economic potential of RES: (1) they do not capture that this economic potential depends on the participation of each energy within the mix, or they do not provide an optimal individual cost within the mix, and (2) do not allow for consensus building among relevant stakeholders.

In 2015, Theodosius et al., Used LCA (Life Cycle Analysis) and MDCM for the design of RES with renewable and conventional sources. Finally, Kim et al., In 2017, used AHP, MAUT, PROMETHEE and ELECTRE in order to compare the results obtained, emphasizing the storage system.

In other references, MCDM tools were applied to guide the decision-making process in different areas of renewable energy, such as energy planning (EP), development of distributed energy systems (DEP), and selection of sustainability indicators (SI).

Table 3 summarizes the fundamental aspects in these studies, as well as those mentioned above, in the field of RES. All of these constitute the trends and are located in the TOS (leaves). 


\begin{tabular}{|c|c|c|c|}
\hline Year: Authors & Methodology & $\begin{array}{l}\text { Energy } \\
\text { sources }\end{array}$ & country \\
\hline $\begin{array}{l}\text { 2011: } \quad \text { Golic; } \\
\text { Manfren }\end{array}$ & $\begin{array}{l}\text { VIKOR; Software } \\
\text { optimization }\end{array}$ & $\begin{array}{l}\text { ST; General } \\
\text { energy }\end{array}$ & Serbia; Italy \\
\hline 2012: Tegou & AHP & W / GT / fuel & Greece \\
\hline $\begin{array}{l}\text { 2013: Trutnevyte; } \\
\text { Yilmaz }\end{array}$ & $\begin{array}{l}\text { EXPAND; } \\
\text { MCDM-MODM }\end{array}$ & $\begin{array}{l}\text { Hy / GT / ST } \\
\text { / Firewood; } \\
\text { Isolated BM }\end{array}$ & $\begin{array}{l}\text { Switzerland; } \\
\text { Turkey }\end{array}$ \\
\hline $\begin{array}{l}\text { 2014: Cannemi; } \\
\text { Hernández; } \\
\text { Mallikarjun }\end{array}$ & $\begin{array}{l}\text { ANP; VIKOR; } \\
\text { DEA / GP }\end{array}$ & $\begin{array}{l}\text { BM; W / PV; } \\
\text { General } \\
\text { energy }\end{array}$ & $\begin{array}{l}\text { Italy; Mexico } \\
\text { Cuba; USES }\end{array}$ \\
\hline $\begin{array}{l}\text { 2015: Jin; Perera; } \\
\text { Theodosious; } \\
\text { Kilkis }\end{array}$ & $\begin{array}{l}\text { WS I GA; FL } \\
\text { TOPSIS; LCA; } \\
\text { REMM (ATMCI) }\end{array}$ & $\begin{array}{l}\text { W / PV; W / } \\
\text { ST / Hy / H2- } \\
\text { T / BM / GT; } \\
\text { GT / BM / W }\end{array}$ & $\begin{array}{l}\text { USES; } \quad \text { Sri } \\
\text { Lanka; Greece; } \\
\text { Turkey }\end{array}$ \\
\hline $\begin{array}{l}\text { 2016: Pankovits; } \\
\text { Xu; Diemuodeke; } \\
\text { Cayir; Kolios; Sun; } \\
\text { Zhang; Zhao }\end{array}$ & $\begin{array}{l}\text { FL, GA; } \\
\text { PROMETHEE II; } \\
\text { TOPSIS; Review; } \\
\text { TOPSIS, } \\
\text { PROMETHEE, } \\
\text { WSM, WPM, AHP, } \\
\text { ELECTRE; } \\
\text { TOPSIS; } \\
\text { Carlo; } \\
\text { VIKOnte }\end{array}$ & $\begin{array}{l}\text { Energy in } \\
\text { general; W / } \\
\text { PV; W / PV / } \\
\text { Diesel; } \\
\text { Energy in } \\
\text { general; W; } \\
\mathrm{W} / \mathrm{PV} \text { / B / } \\
\mathrm{Hy} \mathrm{/} \mathrm{SHy} \mathrm{/} \\
\mathrm{GT} \mathrm{/} \mathrm{TE} \mathrm{/} \mathrm{WE} \\
\text { / OTE; W / } \\
\mathrm{PV;} \mathrm{Electric} \\
\text { vehicles } \\
\end{array}$ & $\begin{array}{l}\text { France; } \\
\text { England; } \\
\text { Nigeria; } \\
\text { Turkey; } \\
\text { England; } \\
\text { China; Hon } \\
\text { Kong; China }\end{array}$ \\
\hline $\begin{array}{l}\text { 2017: Strantzali; } \\
\text { Kim; Soni; Naz; } \\
\text { Cajot; Ioannou; } \\
\text { Chen; Perera; } \\
\text { Malkawi; } \\
\text { Dziugaite- } \\
\text { Tumeniene; } \\
\text { Yousefi; Ali; } \\
\text { Eichhorn; Kazak; } \\
\text { Suuronen; Gentils; } \\
\text { Sagbansua; } \\
\text { Sahabmanesh }\end{array}$ & $\begin{array}{l}\text { PROMETHEE II; } \\
\text { AHP / MAUT / } \\
\text { PROMETHEE / } \\
\text { ELECTRE; WSM / } \\
\text { MILP / NSGA / FL } \\
\text { / GA; Review; } \\
\text { Review; MIQP } \\
\text { mix; FL TOPSIS; } \\
\text { AHP; } \\
\text { ESSINTEGRA; } \\
\text { AHP / GA; AHP / } \\
\text { FTN; GIS / DANP / } \\
\text { MABAC; GIS / } \\
\text { SDSS; AHP / OWA } \\
\text { / GIS; FEA / GA; } \\
\text { AHP / TOPSIS; } \\
\text { AHP }\end{array}$ & $\begin{array}{l}\text { W / LNG / } \\
\text { fuel; Energy } \\
\text { in general; W } \\
\text { / PV; PV / W } \\
\text { / B; Energy } \\
\text { in general; W } \\
\text { / PV / Hy / } \\
\text { H2-T; W / } \\
\text { TG; PV / W / } \\
\text { Batt / ICG; B } \\
\text { / W / PV / ST; } \\
\text { B / Firewood } \\
\text { / PV / ST; PV } \\
\text { / ST / GN / } \\
\text { ICG; W; W; } \\
\text { W; PV; W } \\
\text { offshore; W; } \\
\text { General } \\
\text { energy }\end{array}$ & $\begin{array}{l}\text { Greece; USES; } \\
\text { India; Pakistan; } \\
\text { Germany; } \\
\text { England; } \\
\text { USES; } \\
\text { SriLanka; } \\
\text { Jordan; } \\
\text { Lithuania; Iran; } \\
\text { South Korea; } \\
\text { Germany; } \\
\text { Poland; Chile; } \\
\text { England; } \\
\text { Turkey; Iran }\end{array}$ \\
\hline $\begin{array}{l}\text { 2018: Celli; Li; } \\
\text { Medina-Gonzalez; } \\
\text { Bakhtiari; Ifaei; } \\
\text { Malekpoor; Ray; } \\
\text { McKenna; } \\
\text { Giaouris; Kumar; } \\
\text { Pamucar; } \\
\text { Hajibandeh; } \\
\text { Atabaki; } \\
\text { Sehatpour; } \\
\text { Vishnupriyan; } \\
\text { Chen; Harkouss; } \\
\text { Lotfi; Davtalab; } \\
\text { Xu; Liu }\end{array}$ & $\begin{array}{l}\text { AHP / TOPSIS; } \\
\text { TOPSIS / DEA / } \\
\text { COPRAS; } \\
\text { ELECTRE IV / } \\
\text { MILP; SFLA / } \varepsilon- \\
\text { constrain; FA / } \\
\text { TOPSIS; GRA / } \\
\text { MOGLP; CSA; } \\
\text { MILP (RE3ASON) } \\
\text { / MAVT; EMS, } \\
\text { MILP; TOPSIS } \\
\text { AHP; LNN PW- } \\
\text { CODAS; MM; } \\
\text { AHP / MILP; FL } \\
\text { GP / SIR; AHP; } \\
\text { NSGA II / MOEA / } \\
\text { DA; ELECTRE III; } \\
\text { TOPSIS FL; GIS / } \\
\text { ANP FL / OWA; } \\
\text { TOPSIS / IT2 FNs } \\
\text { FLs; AHP FL }\end{array}$ & $\begin{array}{l}\text { Storage; W / } \\
\text { PV / Diesel; } \\
\text { BM; W / PV / } \\
\text { batt / H2 / T; } \\
\text { PV / WT / } \\
\text { BG / Hy / } \\
\text { SHy / BM; W } \\
\text { / PVT / BM / } \\
\text { Hy / H2- / } \\
\text { Coal / Oil / } \\
\text { Gas / Nuc; W } \\
\text { / PV / } \\
\text { gasificator / } \\
\text { CC / digester; } \\
\text { W / PV / B; } \\
\text { PV / W / } \\
\text { diesel } \\
\text { PEMFC; PV } \\
\text { / W / Diesel / } \\
\text { BB; W / PV / } \\
\text { ST / GT; W; } \\
\text { General } \\
\text { energy; Fuel / } \\
\text { diesel / CNG } \\
\text { / LPG / } \\
\text { Biodiesel; } \\
\text { PV; W / H2- } \\
\text { T PEMFC; } \\
\text { PV / ST Arq; } \\
\text { W; B BM; } \\
\text { Electric } \\
\text { vehicles; W / } \\
\text { PV / B }\end{array}$ & $\begin{array}{l}\text { Italy; } \quad \text { China; } \\
\text { Spain; Iran; } \\
\text { Iran; England; } \\
\text { India; } \\
\text { Germany; } \\
\text { Greece; India; } \\
\text { Libya; } \\
\text { Portugal; Iran; } \\
\text { Iran; India; } \\
\text { China; France; } \\
\text { Iran; Iran; } \\
\text { China; China }\end{array}$ \\
\hline
\end{tabular}

Table 3 Trend summary (TOS sheets) Source: Own Elaboration
According to the number of MODM and MCDM publications found in the trends (Table 4 ), it is observed that $71.2 \%$ of the studies used the MCDM tools, and the most popular were AHP, VIKOR and TOPSIS, due to their easy implementation, and their great flexibility, allowing the inclusion of a large number of criteria for analysis and selection of the closest alternative to the ideal optimal solution.

\begin{tabular}{|l|l|l|l|}
\hline MCDM & \multicolumn{1}{l}{ NP } & \multicolumn{1}{l|}{ MODM } & NP \\
\hline AHP & 13 & DEA & 1 \\
\hline ANP & 2 & GA & 3 \\
\hline VIKOR & 3 & MILP & 2 \\
\hline GP & 1 & COPRAS & 1 \\
\hline PROMETHEE & 2 & SFLA & 1 \\
\hline ELECTRE & 2 & MOGLP & 1 \\
\hline TOPSIS & 8 & CSA & 1 \\
\hline MAUT & 1 & NSGA & 2 \\
\hline CODAS & 1 & MIQP & 1 \\
\hline DEMANTEL & 1 & MOEA & 1 \\
\hline MABAC & 1 & REMM & 1 \\
\hline SIR & 1 & & \\
\hline SDSS & 1 & & \\
\hline
\end{tabular}

Table 4 Number of publications (NP) by MCDM and MODM found in the trends (leaves)

Source: Own Elaboration

Furthermore, in graph 1, it can be seen that the MCDM tools in RES have been more frequently used for their design (23\%) and for the DEP $(17 \%)$. The design of RES is projected as one of the most extensive areas for the application of MCDM tools in the TDG.

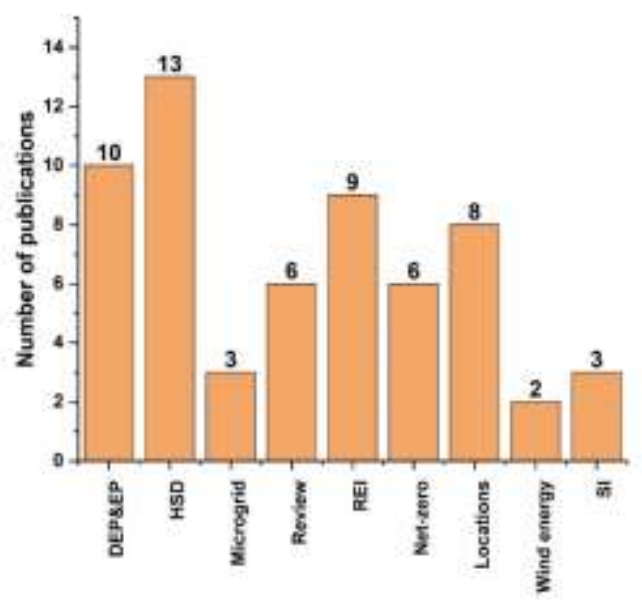

Graphic $1 \mathrm{MCDM}$ in the trends of the THREE Source: Own Elaboration

\section{Discussion}

From the trends section (Leaves) it is notable that, for example, $77 \%$ of the publications considered $\mathrm{W}$ and $\mathrm{PV}$ energies as a synergistic and significant group within renewable sources. 
It can also be observed that such investigations include different types of MCDM tools (TOPSIS, AHP, PROMETHEE II and VIKOR), and MODM methodologies (CSA, MOGLP, SFLA). 56\% applied MCDM tools, being TOPSIS the most common; which coincides with the results of Table 4 due to the frequency of its application to the RES design. Each tool has its own advantages and disadvantages, summarized in Table 5, in which some MCDMs are suggested for the dimensioning or design of RES.

\begin{tabular}{|c|c|c|c|}
\hline MCDM & Advantage & Disadvantages & Chosen because: \\
\hline \multirow{3}{*}{$\begin{array}{l}\text { PROMETHEE } \\
\text { II (Alsayed, } \\
\text { 2014) }\end{array}$} & $\begin{array}{lr}\text { Involves } & \text { all } \\
\text { levels } & \text { of } \\
\text { decision } & \\
\text { making } & \\
\end{array}$ & $\begin{array}{l}\text { Doesn't structure } \\
\text { the goal properly }\end{array}$ & $\begin{array}{l}\text { Take into account } \\
\text { the preferences of } \\
\text { decision-makers }\end{array}$ \\
\hline & $\begin{array}{l}\text { Can take into } \\
\text { account } \\
\text { qualitative and } \\
\text { quantitative } \\
\text { indicators } \\
\end{array}$ & $\begin{array}{l}\text { It is complex, } \\
\text { users must be } \\
\text { experts }\end{array}$ & \multirow[t]{2}{*}{$\begin{array}{l}\text { Define the best } \\
\text { solution among the } \\
\text { alternatives }\end{array}$} \\
\hline & $\begin{array}{l}\text { Incorporates } \\
\text { information } \\
\text { on uncertainty } \\
\text { and diffusivity }\end{array}$ & $\begin{array}{l}\text { The weighting of } \\
\text { the weights } \\
\text { depends on the } \\
\text { decision makers }\end{array}$ & \\
\hline \multirow[b]{2}{*}{$\begin{array}{l}\text { VIKOR } \\
\text { (Hernández, } \\
\text { 2014) }\end{array}$} & $\begin{array}{ll}\text { It is an } \\
\text { improved } \\
\text { version } \\
\text { TOPSIS }\end{array}$ & $\begin{array}{l}\text { Difficulties arise } \\
\text { in conflict } \\
\text { situations }\end{array}$ & \multirow[t]{2}{*}{$\begin{array}{l}\text { Take into account } \\
\text { the preferences of } \\
\text { the main decision- } \\
\text { makers }\end{array}$} \\
\hline & $\begin{array}{l}\text { Calculate the } \\
\text { ratio } \\
\text { positive and } \\
\text { negative } \\
\text { responses, } \\
\text { reducing bias. }\end{array}$ & $\begin{array}{l}\text { Requires } \\
\text { modifications } \\
\text { when data is } \\
\text { similar, presents } \\
\text { difficulties for } \\
\text { real-time } \\
\text { modeling }\end{array}$ & \\
\hline \multirow{3}{*}{$\begin{array}{l}\text { TOPSIS } \\
\text { (Ifaei, 2018) }\end{array}$} & $\begin{array}{l}\text { Establish the } \\
\text { fundamental } \\
\text { order }\end{array}$ & $\begin{array}{l}\text { Principles of } \\
\text { Euclidean } \\
\text { distances that do } \\
\text { not differentiate } \\
\text { between positive } \\
\text { and negative } \\
\text { values }\end{array}$ & $\begin{array}{l}\text { Allows the } \\
\text { implementation of } \\
13 \text { sustainability } \\
\text { criteria }\end{array}$ \\
\hline & $\begin{array}{l}\text { Use all } \\
\text { available } \\
\text { information }\end{array}$ & \multirow{2}{*}{$\begin{array}{l}\text { Attribute values } \\
\text { can be } \\
\text { monotonically } \\
\text { increasing or } \\
\text { decreasing }\end{array}$} & \multirow[t]{2}{*}{$\begin{array}{lr}\text { Allows } & \text { the } \\
\text { construction } & \text { of } \\
\text { large matrices } & \end{array}$} \\
\hline & $\begin{array}{l}\text { The } \\
\text { information } \\
\text { required is not } \\
\text { independent }\end{array}$ & & \\
\hline \multirow{3}{*}{$\begin{array}{l}\text { AHP } \\
\text { (Kim, 2017) }\end{array}$} & Adaptable & $\begin{array}{l}\text { Independence } \\
\text { between } \\
\text { outcomes and } \\
\text { alternatives can } \\
\text { lead to risky } \\
\text { outcomes }\end{array}$ & $\begin{array}{l}\text { It is the most } \\
\text { popular tool in the } \\
\text { field of renewable } \\
\text { energy }\end{array}$ \\
\hline & $\begin{array}{l}\text { Does not } \\
\text { require } \\
\text { complex math }\end{array}$ & $\begin{array}{l}\text { When many } \\
\text { actors are } \\
\text { involved, } \\
\text { weighting the } \\
\text { weights is a } \\
\text { complex process }\end{array}$ & \multirow[t]{2}{*}{$\begin{array}{l}\text { It is the most } \\
\text { popular model in } \\
\text { the administration } \\
\text { of scientific } \\
\text { research and its } \\
\text { applications }\end{array}$} \\
\hline & $\begin{array}{l}\text { Hierarchical } \\
\text { structure } \\
\text { where the } \\
\text { criteria are } \\
\text { well focused } \\
\text { and managed } \\
\text { in a } \\
\text { transparent } \\
\text { way }\end{array}$ & $\begin{array}{l}\text { Requires data } \\
\text { collection based } \\
\text { on experience }\end{array}$ & \\
\hline
\end{tabular}

Table 5 Most Popular MCDMs in Hybrid System Design - Advantages and Disadvantages

Source: Own Elaboration
The methodologies previously analyzed were applied in their basic form or original structure, because they are still in force, as can be seen by the year of publication. The complex implementation of the MCDM is a negative factor, since there are other less difficult options with which similar results can be obtained, easy to implement, with lower requirements and shorter calculation times. Additionally, as suggested by some authors (Connolly et al., 2010; Loken, 2007), the results obtained by a tool must be corroborated using another that agrees, and in the opposite case, a third option that to support two out of three coincidences.

It should be noted that the number of publications that define trends in the use of MCDM tools in RES has increased considerably (Graphic 2) This fact is related to global concern about the problems associated with the use of fossil fuels and their impact on the changes that the Earth is undergoing. Increasingly, academic and scientific institutions, as well as government and society, are involved in the need to carry out energy development in a sustainable way. But, to achieve these goals, it is necessary to take actions that incorporate MCDM tools, to take into account the three pillars of sustainable development and the institutional sphere..

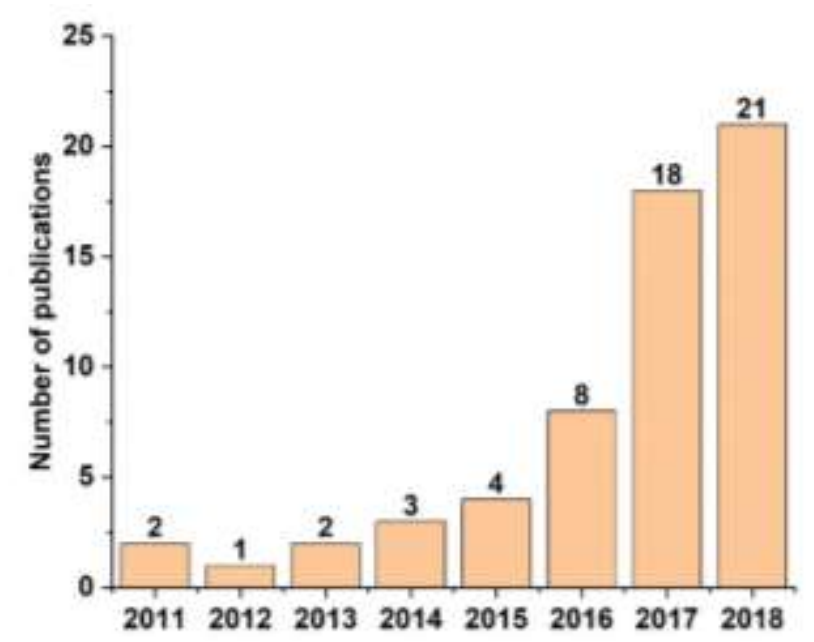

Graphic 2 Publications per year (TOS sheets) Source: Own Elaboration

However, international efforts in this direction have different dimensions between some countries and others; This is evident when analyzing the distribution by country of the publications suggested by TOS, which defined the trends (Graphic 3). 
For example, there is a very low number of publications from Latin American countries. Only Chile, Cuba and Mexico appear, each with a single published case study.

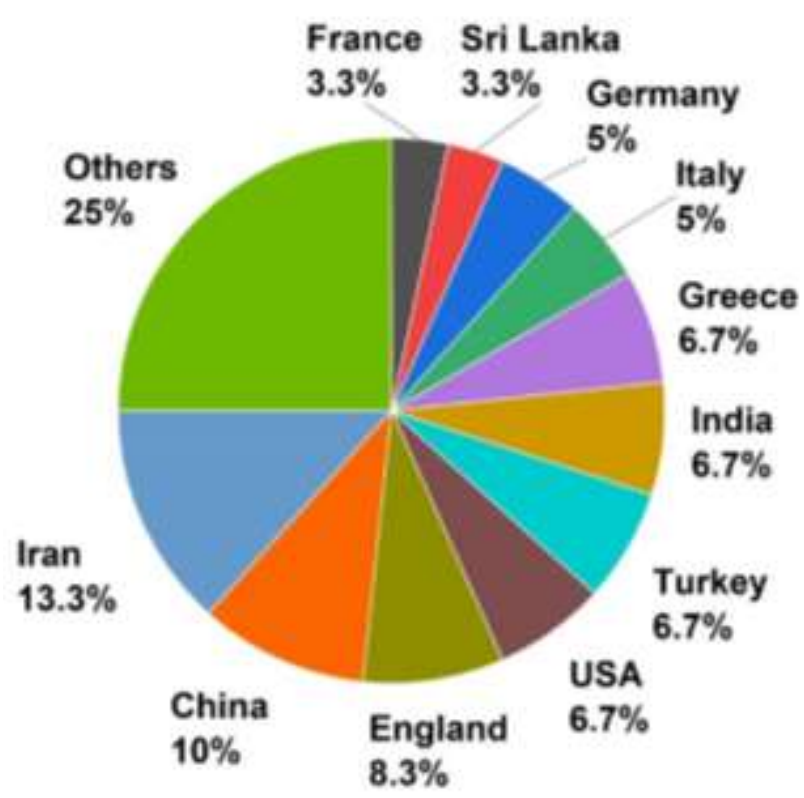

Graphic 3 Publications by country in trends. Others include: Chile, Jordan, Libya, Lithuania, Mexico, Cuba, Nigeria, Pakistan, Poland, Portugal, South Korea, Sri Lanka, Switzerland

Source: Own Elaboration

The MCDM tools are expected to be used more frequently in the renewable energy field and by a larger number of nations, as they can help resolve disagreements among stakeholders during the complex transition from conventional to renewables.

This is where the importance of using the basic structures of the MCDM tools falls, to motivate communities to use them to have support during decision-making processes, which allows support and active participation in energy generation projects based on in one or more renewable sources. Which would ensure its correct operation and functioning throughout the life cycle of the designed project, through stakeholders and involving users.

\section{Annexes}

\section{Nomenclature}

\begin{tabular}{|l|l|}
\hline Batt & Batteries \\
\hline BG & Biogas \\
\hline BM & Biomass \\
\hline CCHP & Combined Cooling, Heating and Power \\
\hline CODAS & Combinative Distance-based Assessment \\
\hline COPRAS & Complex Proportional Assessment \\
\hline DA & Diferential Algorithm \\
\hline DANP & DEMANTEL ANP \\
\hline DEA & Data Envelopment Analysis \\
\hline DEP & Distributed Energy Planning \\
\hline E & Electrolyzer \\
\hline EP & Energy planning \\
\hline EXPANSE & $\begin{array}{l}\text { Exploration of Paterns in Near-Optimal Energy } \\
\text { Scenarios }\end{array}$ \\
\hline FA & Factor Analysis \\
\hline FC & Fuel Cell \\
\hline FEA & Finite Element Analysis \\
\hline GAUF & Geometric Average Utility Function \\
\hline GE & Gas Engine \\
\hline GRA & Gray relational análisis \\
\hline H2-T & Hydrogen Tank \\
\hline HP & Heat Pumps \\
\hline HSD & Hybrid system design \\
\hline Hy & Hydraulics \\
\hline ICG & Internal Combustion Generator \\
\hline LNG & Liquefied Natural Gas \\
\hline MABAC & Multi-Attributive Border Approximation Area \\
\hline Comparison \\
\hline NSGA & Multi-Objective Evolutionary Algorithm \\
\hline PEMFC & Non-Sorting GA \\
\hline PV & Proton Excechance Membrane Fuel Cell \\
\hline REI & Photovoltaics \\
\hline SHy & Renewable Energy Integration \\
\hline SI & Small Hydraulic \\
\hline ST & Sustainability Indicators \\
\hline TG & Thermal Generators \\
\hline TH & Thermal \\
\hline W & Haves \\
\hline
\end{tabular}

\section{Acknowledgments}

The authors express their sincere gratitude to CONACYT (National Council for Science and Technology) for their continued support during this study.

\section{Conclusions}

A bibliographic analysis is presented on the optimization of renewable energy systems using multi-criteria analysis methodologies, according to the references suggested by the tree of science platform (TOS), whose classification into roots, trunk and leaves, facilitated the understanding of the subject. 
It was observed that multi-criteria analysis tools (MCDM) for group decisionmaking (TDG) have been applied successfully to renewable energy systems (RES), mainly because they allow reaching a consensus among stakeholders. These tools also take into account multiple qualitative and quantitative criteria for the evaluation and selection of the best real system. The evolution of methodologies, as well as their application to renewable energy projects began in the early $80 \mathrm{~s}$.

Several studies concluded that decision makers and researchers saw the need to address the flaws of basic methodologies over the years and in different case studies, where they implemented the simulation of uncertainty with methods such as fuzzy logic (FL), approximate numbers (RN) and gray calculations. The methodologies were expanded to other regions where the parameters and inputs differed, as well as the variations in the applied proposal.

It is evident that some methods were not effective in certain cases, because the results depended on the initial values, as well as on the literature analyzed; Therefore, the recommendation of the authors and the experts is to use two or more methodologies in series or in parallel, to reduce the deficiencies and enhance the advantages of each one.

It should be noted that highly complex calculation methods have shown good results, but their implementation is inconvenient. However, some similar methodologies could yield similar results with less complexity and low setup and calculation times.

Finally, it can be said that the area of renewable energies in which the MCDM tools are having greater applicability is the design of renewable hybrid systems under a sustainability approach, therefore, it is highly recommended to work in this direction.

\section{References}

Alsayed, M., Cacciato, M., Scarcella, G., Scelba, G. (2014), "Design of hybrid power generation systems based on multi criteria decision analysis", Solar Energy, vol. 105, pp. 548-560, DOI

http://dx.doi.org/10.1016/j.solener.2014.03.011
Arce, M. E., Saavedra, A., Míguez, J. L., Granada, E. (2015), "The use of grey-based methods in multi-criteria decision analysis for the evaluation of sustainable energy systems: A review ", Renewable and Sustainable Energy Reviews, vol. 47, pp. 924-932, DOI http://dx.doi.org/10.1016/j.rser.2015.03.010

Atabaki, M. S., Aryanpur, V. (2018), "Multiobjective optimization for sustainable development of the power sector: An economic, environmental, and social analysis of Iran", Energy, vol. 161, pp. 493-507, DOI http://dx.doi.org/10.1016/j.energy.2018.07.149

Bakhtiari, H., Naghizadeh, R. A. (2018), "Multicriteria optimal sizing of hybrid renewable energy systems including wind, photovoltaic, battery, and hydrogen storage with $\varepsilon$-constraint method", Renewable Power Generation, vol. 12, num. 8, pp. 883-892, DOI http://dx.doi.org/10.1371/journal.pone.0211642

Baños, R., Manzano-Agugliaro, F., Montoya, G., Gila, C., Alcayde, A., Gomez, J. (2011), "Optimization methods applied to renewable and sustainable energy: A review", Renewable and Sustainable Energy Reviews, vol. 15, pp. 17531766 ,

DOI

http://dx.doi.org/10.1016/j.rser.2010.12.008

Bhattacharyya, S. C. (2012), "Review of alternative methodologies for analyzing off-grid electricity supply", Renewable and Sustainable Energy Reviews, vol. 16, pp. 677-694, DOI http://dx.doi.org/10.1016/j.rser.2011.08.033

Cajot, S., Mirakyan, A., Koch, A., Maréchal, F. (2017), "Multicriteria Decisions in Urban energy System Planning: A Review", Frontiers in Energy Research, vol. 5, num. 10, DOI http://dx.doi.org/10.3389/fenrg.2017.00010

Cannemi, M., García-Melón, M., AragonésBeltrán, P., Gómez-Navarro, T. (2014), "Modeling decision making as a support tool for policy making on renewable energy development", Energy Policy, vol. 67, pp. 127137 , DOI http://dx.doi.org/10.1016/j.enpol.2013.12.011

Cayir, E. B., Eruval, B., Evren, R. (2016), "Optimization Models in Energy: A Literature Review", EGE Academic Review, vol. 16, num. 51 ,

DOI http://dx.doi.org/10.21121/eab.2016OZEL2441 9.

URBANO-ARCILA, Paola Andrea, LASTRES-DANGUILLECOURT, Orlando, HERNÁNDEZ-GALVEZ, Geovanni and IBÁÑEZ-DUHARTE, Guillermo Rogelio. Use of the multicriteria analysis methods to optimize sustainable energy systems based on renewable sources. Journal-Urban-Rural and Regional Economy. 2020 
Çelikbilek, Y., Tüysüz, F. (2016), "An integrated grey based multi-criteria decision making approach for the evaluation of renewable energy sources", Energy, vol. 115, pp. 12461258 ,

DOI http://dx.doi.org/10.1016/j.energy.2016.09.091

Celli, G., Chowdhury, N., Pilo, F., Soma, G. G., Troncia, M., Gianinoni, I. M. (2018), "MultiCriteria Analysis for decision making applied to active distribution network planning", Electric Power Systems Research, vol. 164, pp. 103-111, DOI

http://dx.doi.org/10.1016/j.epsr.2018.07.017

Chen, X., Zhou, H., Li, W., Yu, Z., Gong, G., Yan, Y., Luo, L., Wan, Z., Ding, Y. (2018), "Multi-criteria assessment and optimization study on $5 \mathrm{~kW}$ PEMFC based residential CCHP system", Energy Conversion and Management, vol. 160, pp. 384-395, DOI http://dx.doi.org/10.1016/j.enconman.2018.01.0 50

Chen, Y., Hu, M., Zhou, Z. (2017), "A datadriven analytical approach to enable optimal emerging technologies integration in the cooptimized electricity and ancillary service markets", Energy, vol. 122, pp. 613-626, DOI http://dx.doi.org/10.1016/j.enconman.2018.01.0 50

Connolly, D., Lund, H., Mathiesen, B. V., Leahy, M. (2010), "A review of computer tools for analyzing the integration of renewable energy into various energy systems", Applied Energy, vol. 87, pp. 1059-1082, DOI http://dx.doi.org/10.1016/j.apenergy.2009.09.02 6

Davtalab, M., Alesheikh, A. A. (2018), "Spatial optimization of biomass power plant site using fuzzy analytic network process", Clean Technologies and Environmental Policy, vol. 20, pp. 1033-1046, DOI http://dx.doi.org/10.1007/s10098-018-1531-5

Diemuodeke, E. O., Hamilton, S., Addo, A. (2016), "Multi-criteria assessment of hybrid renewable energy systems for Nigeria's coastline communities", Energy, Sustainability and Society, vol. 6, num. 26, DOI http://dx.doi.org/10.1186/s13705-016-0092-x
Dong, Q., Saaty, T. L. (2014), "An analytic hierarchy process model of group consensus", Journal of Systems Science and System Engineering, vol. 23, num. 3, pp. 362-374, DOI http://dx.doi.org/10.1007/s11518-014-5247-8

Dziugaite-Tumenien, R., Motuziene, V., Siupsinskas, G., Ciuprinskas, K., Rogoza, A. (2017), "Integrated assessment of energy supply system of an energy-efficienthouse", Energy and Buildings, vol. 138, pp. 443-454, DOI http://dx.doi.org/10.1016/j.enbuild.2016.12.058

Eichhorn, M., Tafarte, P., Thran, D. (2017), "Towards energy landscapes e "Pathfinder for sustainable wind power locations"“" Energy, vol. 134, pp. 611-621, DOI http://dx.doi.org/10.1016/j.energy.2017.05.053

Gentils, T., Wang, L., Kolios, A. (2017), "Integrated structural optimisation of offshore wind turbine support structures based on finite element analysis and genetic algorithm", Applied Energy, vol. 199, pp. 187-204, DOI http://dx.doi.org/10.1016/j.apenergy.2017.05.00 9

Georgopoulou, E., Sarafidis, Y., Diakoulaki, D. (1998), "Design and implementation of a group DSS for sustaining renewable energies exploitation", European Journal of Operational Research, vol. 109, pp. 483-500, DOI http://dx.doi.org/10.1016/S0377-

2217(98)00072-1

Giaouris, D., Papadopoulos, A. I., Patsiosa, C., Walker, S., Ziogou, C., Taylor, P., Voutetakis, S., Papadopoulou, S., Seferlis, P. (2018), "A systems approach for management of microgrids considering multiple energy carriers, stochastic loads, forecasting and demand side response", Applied Energy, vol. 226, pp. 546-559, DOI http://dx.doi.org/10.1016/j.apenergy.2018.05.11 3

Golic, K., Kosoric, V., Furundzic, K. A. (2011), "General model of solar water heating system integration in residential building refurbishment-Potential energy savings and environmental impact", Renewable and Sustainable Energy Reviews, vol. 15, pp. 15331544 ,

DOI

http://dx.doi.org/10.1016/j.rser.2010.11.052 
Hajibandeh, N., Shafie-khah, M., Osório, G. J., Aghaei, J., Catalão, J. P. S. (2018), "A heuristic multi-objective multi-criteria demand response planning in a system with high penetration of wind power generators", Applied Energy, vol. 2012, pp. 721-732, DOI http://dx.doi.org/10.1016/j.apenergy.2017.12.07 6

Haralambopoulos, D. A., Polatidis, H. (2003), "Renewable energy projects: structuring a multicriteria group decision-making framework", Renewable Energy, vol. 28, pp. 961-973, DOI http://dx.doi.org/10.1016/S09601481(02)00072-1

Harkouss, F., Fardoun, F., Biwole, P. H. (2018), "Multi-objective optimization methodology for net zero energy buildings", Journal of Building Engineering, vol. 16, pp. 57-71, DOI http://dx.doi.org/10.1016/j.jobe.2017.12.003

Hernández, G., Dorrego, J. R., Núñez, A., Lastres, O., Ixtlilco, L., Juantorena, A., Sarracino, O., Sebastian, P. J. (2014), "Selection of hybrid systems with hydrogen storage based on multiple criteria: application to autonomous systems and connected to the electrical grid", Int. J. Energy Res., vol. 38, pp. 702-713, DOI http://dx.doi.org/10.1002/er.3074

Ifaei, P., Farid, A., Yoo, C. (2018), "An optimal renewable energy management strategy with and without hydropower using a factor weighted multi-criteria decision making analysis and nation-wide big data - Case study in Iran", Energy, vol. 158, pp. 357-372, DOI http://dx.doi.org/10.1016/j.energy.2018.06.043

Ioannou, A., Angus, A., Brennan, F. (2017), "Risk-based methods for sustainable energy system planning: A review", Renewable and Sustainable Energy Reviews, vol. 74, pp. 602615 ,

DOI http://dx.doi.org/10.1016/j.rser.2017.02.082

Jin, T., Yu, Y., Elsayed, E. (2015), "Reliability and quality control for distributed wind/solar energy integration: a multi-criteria approach", IIE Transactions, vol. 47, pp. 1122-1138, DOI http://dx.doi.org/10.1080/0740817X.2015.1009 199
Kaya, T., Kahraman, C. (2010), "Multicriteria renewable energy planning using an integrated fuzzy VIKOR \& AHP methodology: The case of Istanbul", Energy, vol. 35, pp. 2517-2527, DOI http://dx.doi.org/10.1016/j.energy.2010.02.051

Kazak, J., Van Hoof, J., Szewranski, S. (2017), "Challenges in the wind turbines location process in Central Europe - The use of spatial decision support systems", Renewable and Sustainable Energy Reviews, vol. 76, pp. 425433,

http://dx.doi.org/10.1016/j.rser.2017.03.039

Kilkis, S. (2015), "Exergy transition planning for net-zero districts", Energy, vol. 92, pp. 515-531, DOI

http://dx.doi.org/10.1016/j.energy.2015.02.009

Kim, J., Suharto, Y., Daim, T. U. (2017), "Evaluation of Electrical Energy Storage (EES) technologies for renewable energy: A case from the US Pacific Northwest", Journal of Energy Storage, vol. 11, pp. 25-54, DOI http://dx.doi.org/10.1016/j.est.2017.01.003

Kolios, A., Mytilinou, V., Lozano-Minguez, E., Salonitis, K. (2016), "A Comparative Study of Multiple-Criteria Decision-Making Methods under Stochastic Inputs", Energies, vol. 9, pp. 566, DOI http://dx.doi.org/10.3390/en9070566.

Kumar, A., Sah, B., Singh, A. R., Deng, Y., He, X., Kumar, P., Bansal, R. C. (2017), "A review of multi criteria decision making (MCDM) towards sustainable renewable energy development", Renewable and Sustainable Energy Reviews, vol. 69, pp. 596-609, DOI http://dx.doi.org/10.1016/j.rser.2016.11.191

Kumar, A., Singh, A. R., Deng, Y., He, X., Kumar, P., Bansal, R. C. (2018), "A Novel Methodological Framework for the Design of Sustainable Rural Microgrid for Developing Nations", IEEE Access, vol. 6, DOI http://dx.doi.org/10.1109/ACCESS.2018.28324 60.

Li, Y., Shao, S., Zhang, F. (2018), "An Analysis of the Multi-Criteria Decision-Making Problem for Distributed Energy Systems", Energies, vol. 11, pp. 2453, DOI http://dx.doi.org/10.3390/en11092453 
Liu, G., Li, M., Zhou, B., Chen, Y., Liao, S. (2018), "General indicator for techno-economic assessment of renewable energy resources", Energy Conversion and Management, vol. 156, pp. 416-426, DOI http://dx.doi.org/10.1016/j.enconman.2017.11.0 54

Loken, E. (2007), "Use of multicriteria decision analysis methods for energy planning problems", Renewable and Sustainable Energy Reviews, vol. 11, pp. 1584-1595, DOI http://dx.doi.org/10.1016/j.energy.2005.10.023

Lotfi, R., Mostafaeipour, A., Mardani, N., Mardani, S. (2018), "Investigation of wind farm location planning by considering budget constraints", International Journal of Sustainable Energy, vol. 37, num. 8, pp. 799-817, DOI http://dx.doi.org/10.1080/14786451.2018.1437 160

Malekpoor, H., Chalvatzis, K., Mishra, N., Kumar, M., Zafirakis, D., Song, M. (2018), "Integrated grey relational analysis and multi objective grey linear programming for sustainable electricity generation planning", Ann Opererations Research, vol. 269, pp. 475503, DOI http://dx.doi.org/10.1007/s10479-0172566-4

Malkawi, S., Al-Nimr, M., Azizi, D. (2017), "A multi-criteria optimization analysis for Jordan's energy mix", Energy, vol. 127, pp. 680-696, DOI

http://dx.doi.org/10.1016/j.energy.2017.04.015

Mallikarjun, S., Lewis, H. F. (2014), "Energy technology allocation for distributed energy resources: A strategic technology-policy framework", Energy, vol. 72, pp. 783-799, DOI http://dx.doi.org/10.1016/j.energy.2014.05.113

Manfren, M., Caputo, P., Costa, G. (2011), "Paradigm shift in urban energy systems through distributed generation: Methods and models", Applied Energy, vol. 88, pp. 1032-1048, DOI http://dx.doi.org/10.1016/j.apenergy.2010.10.01 8
McKenna, R., Bertsch, V., Mainzer, K., Fichtner, W. (2018), "Combining local preferences with multi-criteria decision analysis and linear optimization to develop feasible energy concepts in small communities", European Journal of Operational Research, vol. 268, pp. 1092-1110, DOI http://dx.doi.org/10.1016/j.ejor.2018.01.036

Medina-González, S., Espuña, A., Puigjaner, L. (2018), "An efficient uncertainty representation for the design of sustainable energy generation systems", Chemical Engineering Research and Design, vol. 131, pp.144-159, DOI http://dx.doi.org/10.1016/j.cherd.2017.11.044

Naz, N. M., Mushtaq, M. I., Naeem, M., Iqbala, M., Altafa, M. W., Haneef, M. (2017), "Multicriteria decision making for resource management in renewable energy assisted microgrids", Renewable and Sustainable energy Reviews, vol. 71, pp. 323-341, DOI http://dx.doi.org/10.1016/j.rser.2016.12.059

Pamucar, D., Badi, I., Sanja, K., Obradovi, R. (2018), "A Novel Approach for the Selection of Power-Generation Technology Using a Linguistic Neutrosophic CODAS Method: A Case Study in Libya", Energies, vol. 11, pp. 2489,

DOI http://dx.doi.org/10.3390/en11092489

Pankovits, P., Abbes, D., Saudemont, C., Brissetc, S., Pougeta, J., Robyns, B. (2016), "Multi-criteria fuzzy-logic optimized supervision for hybrid railway power substations", Mathematics and Computers in Simulation, vol. 130, pp. 236-250, DOI http://dx.doi.org/10.1016/j.matcom.2016.05.00 2

Perera, A. T. D., Attalage, R. A., Perera, K. K. C. K., Dassanayake, V. P. C. (2013), "A hybrid tool to combine multi-objective optimization and multi-criterion decision making in designing standalone hybrid energy systems", Applied Energy, vol. 107, pp. 412-425, DOI http://dx.doi.org/10.1016/j.apenergy.2013.02.04 9 
Perera, A. T. D., Madusanka, N., Attalage, R. A., Perera, K. K. C. K. (2015), "A multi criterion analysis for renewable energy integration process of a standalone hybrid energy system with internal combustion generator", Journal of Renewable and Sustainable. Energy, vol. 7, 043128,

DOI

http://dx.doi.org/10.1063/1.4928684

Pohekar, S. D., Ramachandran. M. (2004), "Application of multi-criteria decision making to sustainable energy planning-A review", Renewable and Sustainable Energy Reviews, vol. 8, pp. 365-381, DOI http://dx.doi.org/10.1016/j.rser.2003.12.007

Ray, A., Jana, K., Assadi, M., De, S. (2018), "Distributed polygeneration using local resources for an Indian village: multiobjective optimization using metaheuristic algorithm", Clean Technologies and Environmental Policy, vol. 20, pp.1323-1341, DOI http://dx.doi.org/10.1007/s10098-018-1562-y

Ribeiro, F., Ferreira, P., Araújo, M. (2013), "Evaluating future scenarios for the power generation sector using a Multi-Criteria Decision Analysis (MCDA) tool: The Portuguese case", Energy, vol. 52, pp. 126-136, DOI

http://dx.doi.org/10.1016/j.energy.2012.12.036

Robledo-Giraldo, S., Osorio-Zuluaga, G. A., López-Espinosa, C. (2014), "Networking en pequeña empresa: una revisión bibliográfica utilizando la teoría de grafos", Revista Vínculos, vol. 11, num. 2, pp. 6-16, DOI http://dx.doi.org/10.14483/2322939X.9664

Sagbansua, L., Balo, F. (2017), "Decision making model development in increasing wind farm energy Efficiency", Renewable Energy, vol. 109, pp. 354-362, DOI http://dx.doi.org/10.1016/j.renene.2017.03.045

Sahabmanesh, A., Saboohi, Y. (2017), "Model of sustainable development of energy system, case of Hamedan", Energy Policy, vol. 104, pp. 66-79, DOI http://dx.doi.org/10.1016/j.enpol.2017.01.039

Scott, J. A., Ho, W., Dey, P. K. (2012), "A review of multi-criteria decision-making methods for bioenergy systems", Energy, vol. 42, pp. 146-156, DOI http://dx.doi.org/10.1016/j.energy.2012.03.074
Sehatpour, M., Kazemi, A. (2018), "Sustainable fuel portfolio optimization: Integrated fuzzy multi-objective programming and multi-criteria decision making", Journal of Cleaner Production, vol. 176, pp. 304-319, DOI http://dx.doi.org/10.1016/j.jclepro.2017.12.092

Sengül, Ü., Eren, M., Shiraz, S. E., Gezder, V., Sengül, A. B. (2015), "Fuzzy TOPSIS method for ranking renewable energy supply systems in Turkey", Renewable Energy, vol. 75, pp. 617625 ,

DOI http://dx.doi.org/10.1016/j.renene.2014.10.045

Soni, A., Stagner, J. A., Ting, D. S. K. (2017), "Adaptable wind/solar powered hybrid system for household wastewater treatment", Sustainable Energy Technologies and Assessments, vol. 24, pp. 8-18, DOI http://dx.doi.org/10.1016/j.seta.2017.02.015

Strantzali, E., Aravossisa, K., Livanos, G. A. (2017), "Evaluation of future sustainable electricity generation alternatives: The case of a Greek island", Renewable and Sustainable Energy Reviews, vol. 76, pp. 775-787, DOI http://dx.doi.org/10.1080/23311916.2016.1167 990

Sun, X., Zhang, B., Tang, X., McLellan, B. C., Höök, M. (2016), "Sustainable Energy Transitions in China: Renewable Options and Impacts on the Electricity System", Energies, vol. 9, num 12, pp. 980, DOI http://dx.doi.org/10.3390/en9120980

Suuronen, A., Lensu, A., Kuitunen, M., Andrade-Alvear, R., Guajardo-Celis, N., Miranda, M., Perez, M., Kukkonen, J. V. K. (2017), "Optimization of photovoltaic solar power plant locations in northern Chile", Environmental Earth Sciences, vol. 76, pp. 824, DOI http://dx.doi.org/10.1007/s12665-0177170-z

Tahri, M., Hakdaoui, M., Maanan, M. (2015), "The evaluation of solar farm locations applying Geographic Information System and MultiCriteria Decision-Making methods: Case study in southern Morocco", Renewable and Sustainable Energy Reviews, vol. 51, pp. 13541362,

DOI http://dx.doi.org/10.1016/j.rser.2015.07.054 
Tegou, L. I., Polatidis, H., Haralambopoulos, D. A. (2012), "A Multi-Criteria Framework for an Isolated Electricity System Design with Renewable Energy Sources in the Context of Distributed Generation: The Case Study of Lesvos Island, Greece", International Journal of Green Energy, vol. 9, pp. 256-279, DOI http://dx.doi.org/10.1080/15435075.2011.6214 84

Theodosiou, G., Stylos, N., Koroneos, C. (2015), "Integration of the environmental management aspect in the optimization of the design and planning of energy systems", Journal of Cleaner Production, vol. 106, pp. 576-593, DOI http://dx.doi.org/10.1016/j.jclepro.2014.05.096

Trutnevyte, E. (2013), "EXPANSE methodology for evaluating the economic potential of renewable energy from an energy mix perspective", Applied Energy, vol. 111, pp. 593-601,

DOI http://dx.doi.org/10.1016/j.apenergy.2013.04.08 3

Tsoutsos, T., Drandaki, M., Frantzeskaki, N., Iosifidis, E., Kiosses, I. (2009), "Sustainable energy planning by using multi-criteria analysis application in the island of Crete", Energy Policy, vol. 37, pp. 1587-1600, DOI http://dx.doi.org/10.1016/j.enpol.2008.12.011

Vishnupriyan, J., Manoharan, P. S. (2018), "Multi-criteria decision analysis for renewable energy integration: Asouthern India focus", Renewable Energy, vol. 121, pp. 474-488, DOI http://dx.doi.org/10.1016/j.renene.2018.01.008

Wang, J. J., Jing, Y. Y., Zhang, C. F., Zhao, J. H. (2009), "Review on multi-criteria decision analysis aid in sustainable energy decisionmaking", Renewable and Sustainable Energy Reviews, vol. 13, pp. 2263-2278, DOI http://dx.doi.org/10.1016/j.rser.2009.06.021

Xu, B., Nayak, A., Gray, D., Ouenniche, J. (2016), "Assessing energy business cases implemented in the North Sea Region and strategy recommendations", Applied Energy, vol. 172, pp. 360-371, DOI http://dx.doi.org/10.1016/j.apenergy.2016.03.11 0
Xu, J., Lin Zhong, L., Yao, L., Wu, Z. (2018), "An interval type-2 fuzzy analysis towards electric vehicle charging station allocation from a sustainable perspective", Sustainable Cities and Society, vol. 40, pp. 335-351, DOI http://dx.doi.org/10.1016/j.scs.2017.12.010

Yilmaz, S., Selim, H. (2013), "A review on the methods for biomass to energy conversion systems design", Renewable and Sustainable Energy Reviews, vol. 25, pp. 420-430, DOI http://dx.doi.org/10.1016/j.rser.2013.05.015

Yousefi, H., Ghodusinejad, M. H., Noorollahi, Y. (2017), "GA/AHP-based optimal design of a hybrid CCHP system consideringeconomy, energy and emission", Energy and Buildings, vol. 138, pp. 309-317, DOI http://dx.doi.org/10.1016/j.enbuild.2016.12.048 Zhang, S., Huang, P., Sun, Y. (2016), "A multicriterion renewable energy system design optimization for net zero energy buildings under uncertainties", Energy, vol. 94, pp. 654-665, DOI

http://dx.doi.org/10.1016/j.energy.2015.11.044

Zhao, H., Li, N. (2016), "Optimal Siting of Charging Stations for Electric Vehicles Based on Fuzzy Delphi and Hybrid Multi-Criteria Decision Making Approaches from an Extended Sustainability Perspective", Energies, vol. 9, pp. 270, DOI http://dx.doi.org/10.3390/en9040270.

Zhou, P., Ang, B. W., Poh, K. L. (2006), "Decision analysis in energy and environmental modeling: An update", Energy, vol. 31, pp. 2604-2622, DOI http://dx.doi.org/10.1016/j.energy.2005.10.023 